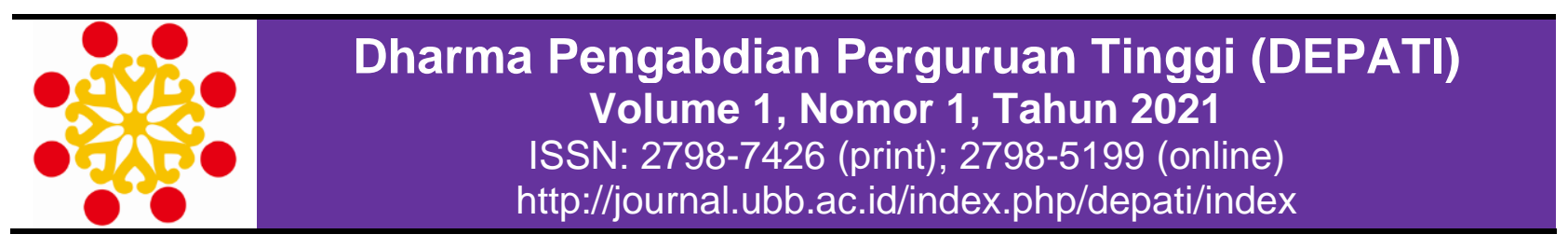

\title{
PENDAMPINGAN GURU MADRASAH DI KOTA SERANG DALAM PEMBUATAN ALAT PRAKTIKUM FISIKA BERBASIS HIGHER ORDER THINKING SKILLS (HOTS)
}

\author{
Asep Saefullah ${ }^{1, *}$, Yuvita Oktarisa ${ }^{1}$, Muhammad Fatkhurrokhman², Lukman \\ Nulhakim $^{3}$, dan Diana Ayu Rostikawati ${ }^{4}$ \\ 1)Pendidikan Fisika, Fakultas Keguruan dan IImu Pendidikan, Universitas sultan Ageng Tirtayasa \\ Jl. Ciwaru Raya. No.25, Kota Serang, Banten, Indonesia \\ 2) Pendidikan Vokasional Teknik Elektro, Fakultas Keguruan dan Ilmu Pendidikan, Universitas Sultan \\ Ageng Tirtayasa \\ Jl. Ciwaru Raya. No.25, Kota Serang, Banten, Indonesia \\ 3)Pendidikan IPA, Fakultas Keguruan dan IImu Pendidikan, Universitas Sultan Ageng Tirtayasa \\ Jl. Ciwaru Raya. No.25, Kota Serang, Banten, Indonesia \\ 4)Teknik Industri, Fakultas Sains dan Teknologi, Universitas Bina Bangsa \\ Jl. Raya Serang-Jakarta km.03 No 1B, Kota Serang, Banten
}

${ }^{*}$ E-mail korespondensi: asaefullah@untirta.ac.id

\section{Info Artikel: Abstract}

Dikirim:

25 Maret 2021

Revisi:

26 April 2021

Diterima:

26 Mei 2021

\section{Kata Kunci: \\ Guru Madrasah, \\ Alat Praktikum \\ Fisika, Higher \\ Order Thinking \\ Skills (HOTS)}

Madrasah is one of the formal educational institutions that aims to develop students' potential to the maximum. The skills acquired by students are expected to be sufficient provisions for students to compete globally but still pay attention to local wisdom. Madrasah teachers must be able to equip themselves to be able to become reliable facilitators so that they can lead students to the gates of independence. Madrasah teachers must equip students to have Higher Order Thinking Skills (HOTS). HOTS can equip madrasah students to have the ability to think critically, creatively, logically, and systematically. Practicum activity is one of the lessons that can be done so that students have HOTS. However, madrasah teachers are often confronted with the inadequacy of the school's physics practicum tools. Through this community service activity, teachers receive assistance on making physics practicum tools and their guidelines. In addition, teachers also receive assistance on how to manage learning that can train HOTS. The results of community service show that madrasah teachers can make physics practicum tools that can be used in HOTS-based learning.

\begin{abstract}
Abstrak
Madrasah merupakan salah satu lembaga pendidikan formal yang bertujuan mengembangkan potensi peserta didik secara maksimal. Keterampilan yang diperoleh siswa diharapkan dapat menjadi bekal yang cukup bagi siswa untuk dapat bersaing secara global, namun tetap memperhatikan kearifan lokal. Guru madrasah harus dapat membekali diri agar mampu menjadi fasilitator yang handal, sehingga dapat mengantarkan siswa ke gerbang kemandirian. Guru madrasah harus membekali siswa agar memiliki kemampuan berpikir tingkat tinggi atau Higher Order Thinking Skills (HOTS). HOTS dapat membekali siswa madrasah agar dapat memiliki kemampuan berpikir kritis, kreatif, logis dan sistematis. Kegiatan praktikum merupakan salah satu pembelajaran yang dapat dilakukan agar siswa memiliki HOTS. Namun, guru madrasah kerap dibenturkan pada kurang memadainya alat praktikum fisika yang dimiliki sekolah. Melalui kegiatan pengabdian pada masyarakat ini, guru mendapatkan pendampingan bagaimana membuat alat praktikum fisika beserta panduannya. Selain itu, guru juga mendapatkan pendampingan bagaimana mengelola pembelajaran yang dapat melatihkan HOTS. Hasil pengabdian kepada masyarakat menunjukan bahwa guru madrasah sudah mampu membuat alat praktikum fisika yang dapat dimanfaatkan dalam pembelajaran berbasis HOTS.
\end{abstract}




\section{PENDAHULUAN}

Perkembangan ilmu pengetahuan dan teknologi (IPTEK) merupakan hal yang tldak dapat terelakkan. Menghadapi perkembangan IPTEK, pendidikan harus mempersiapkan siswa agar memiliki keterampilan dalam menggunakan teknologi untuk menghadapi tantangan di abad 21 . Dalam uppaya membekali peserta didik menghadapi tantanga abad 21, UNESCO pada tahun 1996 menetapkan empat pilar pendidikan yaitu "learning to know, learning to do, learning to be, dan learning to live together" [1]. Hal ini didukung dengan definisi pendidikan yaitu usaha sadar dan terencana untuk mewujudkan suasana belajar dan proses pembelajaran agar peserta didik secara aktif mengembangkan potensi dirinya untuk memiliki kekuatan spiritual keagamaan, pengendalian diri, kepribadian, kecerdasan, akhlak mulia, serta keterampilan yang diperlukan dirinya [2].

Arti utama dari pendidikan ini seyogyanya menjadi landasan bagi sekolah formal yang ada di Indonesia, tidak terkecuali madrasah. Madrasah merupakan lembaga pendidikan yang pada dasarnya sama dengan sekolah umum namun memiliki beberapa mata pelajaran khas Agama Islam. Madrasah sebagai salah satu bagian dari pendidikan, menjadi tempat yang juga berperan penting dalam melaksankan proses pembelajaran. Proses pembelajaran merupakan salah satu komponen penting untuk terwujudnya pendidikan yang berkualitas [3]. Berdasarkan hasil wawancara dengan beberapa guru madrasah, mutu pendidikan madrasah belum optimal dikembangkan, sehingga tujuan utama pendidikan belum dapat terlaksana sepenuhnya.

Terdapat dua Indikator kualitas pendidikan, yaitu proses pendidikan dan hasil pendidikan. Proses pendidikan memiliki standar khusus sehingga dapat menghasilkan pendidikan sesuai dengan standar minimal kompetensi lulusan [4]. Standar minimal proses pendidikan meliputi beberapa komponen, seperti : metodologi dalam pembelajaran, bahan ajar, sarana dukungan administrasi, sarana prasarana dan berbagai sumber daya lainnya. Keseluruhan komponen harus dimanfaatkan secara maksimal agar dapat menghasilkan siswa yang sesuai dengan standar kompetensi lulusan yang telas ditetapkan.

Fisika merupakan salah satu mata pelajaran yang terdapat dalam kurikulum Madrasah Aliyah (MA). Pada kurikulum tahun 2013, salah satu tujuan mata pelajaran fisika ialah "Mengembangkan pengalaman untuk merumuskan maslah, mengajukan dan menguji hipotesis melalui percobaan, merancang dan merakit instrumen percobaan, mengumpulkan, mengolah, dan menafsirkan data, serta mengomunikasikan hasil percobaan secara lisan dan tertulis". Mengingat fungsi sentral dari mata pelajaran fisika di madrasah, maka seyogyanya pelaksanaan proses belajar mata pelajaran fisika di tingkat madrasah dapat dioptimalkan seefektif mungkin. Pentingnya usaha untuk mengoptimalkan proses belajar pada mata pelajaran fisika di madrasah dikuatkan dengan kurangnya hasil penelitian pendidikan terutama dalam mata pelajaran fisika di tingkat madrasah [5].

Kurangnya hasil penelitian pendidikan pada tingkat madrasah khususnya pada mata pelajaran fisika menandakan belum adanya upaya optimal dalam mengatasi masalah pada pembelajaran fisika, sehingga hasil pendidikan tidak dapat memenuhi standar minimal yang diharapkan [6]. Tidak tercapainya standar kelulusan yang diharapkan ditandai dengan rendahnya rata-rata hasil Ujian Nasional Madrasah khususnya mata pelajaran fisika.

Setelah menginvestigasi beberapa madrasah di Kota Serang, Provinsi Banten, terungkap informasi bahwa proses belajar fisika lebih menitikberatkan pada proses menjawab soal dan pertanyaan. Kurangnya upaya untuk melatihkan kemampuan selain menjawab soal dan pertanyaan mengakibatkan tidak tercapainya tujuan pembelajaran fisika sepenuhnya, terutama untuk melatih kemampuan merumuskan masalah, mengajukan hipotesis, mengumpulkan data dan berpikir ilmiah [7]. Proses pembelajaran konvensional yang biasanya berlangsung dikelas tidak melatih HOTS. Kegiatan pembelajaran tradisional diawali dengan memberikan serangkaian informasi yang berkaitan dengan teori, memberikan contoh dan diakhiri dengan latihan soal. Selain itu dalam pembelajaran yang bersifat konvensional proses belajar terpusat pada guru dan siswa bertugas hanya sebagai pendengar yang berfungsi untuk diberi tahu bukan mencari tahu.

Dalam memecahkan persoalan yang diberikan pada siswa, siswa cenderung hanya menghafalkan bagaimana langkah-langkah pemecahan soal, sehingga siswa tidak dilatih untuk berpikir pada tingkat yang lebih tinggi. Kurangnya upaya untuk melatih kemampuan tingkat tinggi pada siswa dipertegas oleh hasil pengukuran literasi sains yang dilakukan oleh 
Programme for International Student Assessment (PISA) [8]. Literasi sains mengukur kemampuan siswa dalam tiga ranah yaitu konteks, konten dan proses, ketiga kemampuan ini merupakan bagian dari HOTS [9]. Hasil pengukuran literasi sains pada tahun 2015, nilai literasi sains siswa Indonesia berada pada urutan 63 dari 72 negara yang ikut berpartisipasi dalam penilaian literasi sains siswa di dunia. Selain hasil dari PISA, Trends in International Mathematics and Science Study (TIMSS) menunjukkan hal yang tidak jauh berbeda [10]. Secara keseluruhan, siswa Indonesia kurang pada semua aspek konten maupun kognitif, baik sains atupun matematika. Siswa Indonesia perlu menguatkan upaya untuk dapat melatih keterampilan mengintegrasikan informasi, menarik kesimpulan, juga mengeneralisir pengetahuan yang dimiliki [11].

Melihat kondisi pencapaian siswa dalam pembelajaran fisika yang merupakan bagian dari literasi sains dan kemampuan kognitif yang diujikan oleh TIMSS, dapat disimpulkan bahwa kurangnya pelatihan kemampuan berpikir tingkat tinggi dalam proses pembelajaran menjadi sumber permasalahan. Salah satu cara untuk melatihkan kemampuan tingkat tinggi dapat dilakukan dengan melakukan eksperimen pada proses pembelajaran. Melalui proses eksperimen, siswa difasilitasi untuk menemukan konsep sehingga pembelajaran lebih bermakna [12]. Beberapa penelitian membuktikan bahwa kegiatan eksperimen mampu meningkatkan pemahaman konsep siswa sehingga kemampuan HOTS dapat dilatih [13]. Akan tetapi belum semua madrasah optimal dalam mengembangkan kegiatan laboratorium. Minimnya kegiatan eksperimen pada proses pembelajaran fisika berdampak pada kurangnya HOTS yang dimiliki siswa, sehingga siswa tidak mampu untuk membaca grafik, menginterpretasi data, melakukan eksperimen, berhipotesis dan menyelesaikan permasalahan [14]. Terdapat dua penyebab utama kurang optimalnya kegiatan laboratorium di Madrasah yang ada di Kota Serang, yaitu :

1. Sebagian besar guru fisika madrasah di Kota Serang berlatar belakang pendidikan bukan dari Pedidikan Fisika sehingga kurang mampu untuk mengelola laboratorium.

2. Kurangnya peralatan laboratorium membatasi jumlah praktikum yang dapat dilakukan.

Diharapkan dengan melakukan pendampingan pembuatan alat praktikum fisika beserta penuntunnya bagi para guru fisika madrasah Kota Serang, para guru dapat menciptakan alat praktikum yang mampu dimanfaatkan dalam pembelajran fisika yang menyenangkan, sehingga dapat memfasilitasi HOTS.

\section{METODE PELAKSANAAN}

Secara umum, metode pelaksanaan kegiatan pengabdian kepada masyarakat ini dijabarkan dalam 2 kegiatan sebagai berikut :

1. Workshop dan pendampingan pembuatan alat praktikum fisika pada materi kelistrikan dan kemagnetan, yaitu membuat alat praktikum hukum Ohm dan alat praktikum motor listrik.

2. Workshop dan pendampingan penyusunan panduan praktikum hukum Ohm dan motor listrik berbasis HOTS.

Secara lebih rinci, kedua kegiatan di atas diuraikan dalam 3 tahapan kegiatan, seperti terlihat pada Tabel 1 berikut ini. 
Tabel 1. Metode Pelaksanaan

\begin{tabular}{|c|c|}
\hline $\begin{array}{l}\text { Tahapan } \\
\text { kegiatan }\end{array}$ & Kegiatan yang dilaksanakan \\
\hline Persiapan & $\begin{array}{l}\text { Hal yang dilakukan dalam tahapan persiapan adalah } \\
\text { 1) Menyusun karya tulis berupa makalah yang berisikan materi } \\
\text { pembelajaran fisika berbasis HOTS yang memuat fakta atau fenomena } \\
\text { yang sesuai dengan proses pembelajaran, isi, kompetensi lulusan, } \\
\text { penilaian dalam proses berpikir tingkat tinggi dalam bentuk silabus, } \\
\text { RPP, lembar kerja siswa yang digunakan dalam eksperimen fisika } \\
\text { madrasah; } \\
\text { 2) Membuat desain dan kerangka awal alat praktikum fisika sederhana } \\
\text { yang sesuai dengan perangkat pembelajaran yang dikembangkan, } \\
\text { sehingga dapat menunjang pembelajaran dan mampu memfasilitasi } \\
\text { siswa untuk dapat berpikir tingkat tinggi. } \\
\text { 3) Membuat alat evaluasi berupa instrumen tes untuk mengetahui } \\
\text { pengetahuan dan kemampuan awal dan akhir guru sebelum dan } \\
\text { sesudah kegiatan. }\end{array}$ \\
\hline Pelak & $\begin{array}{l}\text { Kegiatan ini dilaksanakan melalui workshop pembuatan alat praktikum } \\
\text { fisika sederhana dilengkapi dengan penyusunan perangkat pembelajaran } \\
\text { untuk kegiatan eksperimen menurut alat yang dikembangkan berbasis } \\
\text { HOTS bagi guru fisika madrasah dengan pelaksanaan teknis sebagai } \\
\text { berikut. } \\
\text { 1) Mempersiapkan kegiatan workshop, mulai dari menyusun jadwal } \\
\text { kegiatan sampai menentukan tempat pelaksanaan. } \\
\text { 2) Mengundang narasumber pembelajaran berbasis HOTS yang dapat } \\
\text { memberikan arahan mengenai penyusunan panduan praktikum fisika } \\
\text { berbasis HOTS. Selain itu para ahli juga dapat memberikan arahan } \\
\text { mengenai alat praktikum fisika sederhana yang dpat dikembangkan } \\
\text { agar proses pembelajaran berbasis HOTS dapat diimplementasikan. } \\
\text { 3) Mengundang para guru fisika madrasah sebagai peserta workshop } \\
\text { sehingga dapat mengembangkan alat fisika sederhana agar kegiatan } \\
\text { eksperimen di sekolah dapat dilaksanakan. } \\
\text { 4) Mengundang para guru fisika madrasah untuk mengikuti workshop } \\
\text { penyusunan panduan praktikum fisika berbasis HOTS yang kemudian } \\
\text { akan digunakan untuk kegiatan pembelajaran praktikum fisika di } \\
\text { sekolah. } \\
\text { 5) Mendokumentasikan dan memublikasikan kegiatan workshop. }\end{array}$ \\
\hline $\begin{array}{c}\text { Evaluasi/ } \\
\text { Pendampingan }\end{array}$ & $\begin{array}{l}\text { Kegiatan dalam tahapan evaluasi dan pendampingan ialah: } \\
\text { 1) Melakukan pendampingan pada para guru fisika dalam pembuatan alat } \\
\text { praktikum fisika sederhana berbasis HOTS dan melihat kesesuaian } \\
\text { antara perangkat pembelajaran yang dibuat dengan Kompetensi Inti } \\
\text { (KI) dan Kompetensi Dasar (KD), juga strategi pembelajaran. } \\
\text { 2) Memvalidasi alat praktikum fisika sederhana yang dibuat melalui } \\
\text { validasi ahli, selain itu valiasi juga melibatkan siswa sehingga dapat } \\
\text { dilihat ketergunaan alat yang dibuat dan digunakan. } \\
\text { 3) Menilai dan mengevaluasi pembelajaran yang dilakukan oleh guru } \\
\text { berdasarkan indikator-indikator yang telah disepakati dengan pakar } \\
\text { pada kegiatan pelaksanaan sehingga pembelajaran yang inovatif, } \\
\text { interaktif, inspiratif, menyenangkan sesuai dengan minat dan bakat } \\
\text { peserta didik dapat terlaksana dengan baik. } \\
\text { 4) Evaluasi hasil belajar sehingga memberikan penilaian yang autentik. }\end{array}$ \\
\hline
\end{tabular}




\section{HASIL DAN PEMBAHASAN}

Kegiatan sosialisasi dengan sekolah mitra Pengabdian Pada Masyarakat (P2M) pada Program Kemitraan Masyarakat (PKM) dilakukan dalam dua hari, yaitu pada tanggal 5 dan 6 Maret 2018. Pada hari pertama tanggal 5 Maret 2018, sosialisasi dilakukan dengan madrasah mitra 1, yaitu Madrasah Aliyah (MA) Al Rahmah. Sementara kegiatan sosialisasi dengan sekolah mitra 2, yaitu SMA IT Nuur El Bantany dilakukan pada tanggal 6 maret 2018. Kegiatan sosialisasi hanya berupa kegiatan diskusi ringan antara tim pengusul pengabdian dengan madrasah mitra, yaitu mensosialisasikan bahwa proposal Pengabdian Pada Masyarakat (P2M) yang berjudul "Pendampingan Guru Madrasah di Kota Serang Dalam Pembuatan Alat Praktikum Fisika Berbasis Higher Order Thinking Skills (HOTS)" pada Program Kemitraan Masyarakat (PKM) disetujui dan didanai oleh Kementerian Riset Teknologi dan Pendidikan Tinggi (Kemenristek Dikti). Dengan disetujui dan didanainya proposal tersebut, maka dalam waktu dekat akan diadakan kegiatan workshop pendampingan pembuatan alat praktikum fisika berbasis HOTS untuk para guru madrasah sekolah mitra. Alat praktikum itu sendiri harus dilengkapi dengan panduan petunjuk penggunaannya. Sehingga selain diadakan kegiatan workshop pembuatan alat praktikum, akan diadakan pula kegiatan workshop penyusunan panduan praktikum fisika berbasis HOTS.

Kegiatan diskusi rancangan alat praktikum fisika dengan madrasah mitra dilakukan pada tanggal 2 dan 3 April 2018. Pada tanggal 2 April 2018, kegiatan diskusi dilaksanakan dengan mitra 1, sementara diskusi rancangan alat praktikum fisika dengan mitra 2 dilaksanakan pada hari berikutnya, yaitu 3 April 2018. Kegiatan diskusi berlangsung sangat cair, membicarakan kebutuhan alat praktikum fisika untuk proses pembelajaran yang dibutuhkan madrasah. Alat praktikum yang akan dibuat tentunya harus memiliki kepraktisan, sehingga dapat digunakan di manapun (termasuk di dalam kelas) tanpa harus bergantung fasilitas penunjang, semisal jaringan listrik. Dari hasil kegiatan diskusi dengan mitra 1 dan 2, maka rancangan alat praktikum yang akan dibuat dalam kegiatan workshop adalah alat praktikum hukum Ohm dan Motor listrik.

Sebelum pelaksanaan kegiatan workshop pembuatan alat praktikum fisika berbasis HOTS untuk guru madrasah se-Kota Serang, tim pengusul terlebih dahulu melaksanakan pelatihan kepada empat orang mahasiswa yang akan menjadi fasilitator dalam kegiatan workshop seperti ditunjukkan Gambar 1. Keempat mahasiswa tersebut adalah Vaka Gustiono dan Seno Indriyanto dari jurusan Pendidikan Teknik Elektro, serta Resty Dwi Asry dan Hayin Rosdiana Azhari dari jurusan Pendidikan Fisika. Dipilihnya dua mahasiswa pendidikan fisika dikarenakan keduanya memiliki konsep yang baik mengenai keilmuan fisika, sementara dua mahasiswa pendidikan teknik elektro dipilih karena memiliki kecakapan dalam hal pembuatan alat. Dengan kombinasi mahasiswa dua jurusan tersebut diharapkan kegiatan persiapan sampel alat praktikum fisika akan berjalan lebih mudah.

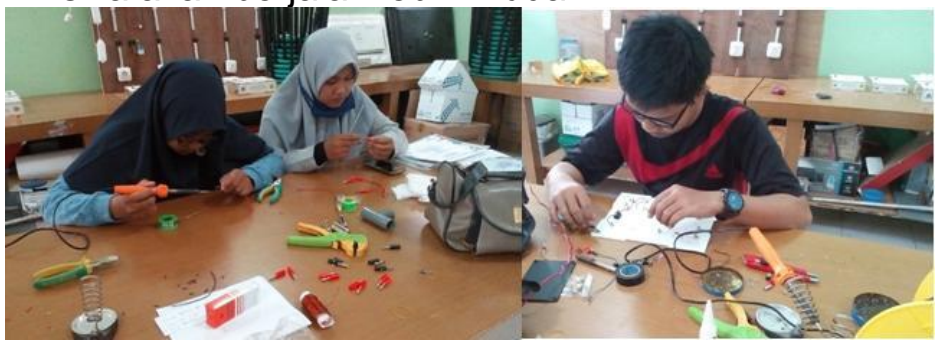

\section{Gambar 1. Kegiatan mahasiswa dalam mencoba dalam pembuatan alat praktikum fisika}

Keberadaan fasilitator dari mahasiswa diharapkan akan mempermudah para guru madrasah saat proses pembuatan alat praktikum fisika dalam kegiatan workshop. Dalam kegiatan persiapan, mahasiswa dilatih untuk mencoba membuat, merangkai, dan menguji coba alat praktikum fisika. Keterlibatan mahasiswa dalam kegiatan pengabdian pada masyarakat ini juga bertujuan agar menambah pengetahuan dan keterampilan mahasiswa dalam membuat alat praktikum.

Kegiatan workshop pembuatan alat praktikum fisika untuk guru madrasah se-Kota Serang dilaksanakan pada hari Senin, 28 Mei 2018 di Laboratorium Vokasional Teknik Elektro FKIP 
Untirta. Nasasumber kegiatan workshop tersebut berasal dari internal Untirta yaitu Mohammad Fatkhurrokhman, M.Pd yang merupakan dosen pada jurusan pendidikan Teknik Elektro FKIP Untirta. Dalam kegiatan workshop, narasumber memaparkan materi berupa pengenalan alatalat praktikum fisika yang berbasis HOTS, cara pembuatan alat serta pengenalan alat dan bahan yang akan digunakan dalam pembuatan alat praktikum fisika tersebut. Kemudian diadakan sesi tanya jawab bagi peserta workshop. Pada kegiatan ini, nampak sekali bahwa para peserta workshop yang terdiri dari 25 orang guru madrasah sangat antusias dalam mengikuti workshop tersebut seperti ditunjukkan pada Gambar 2.

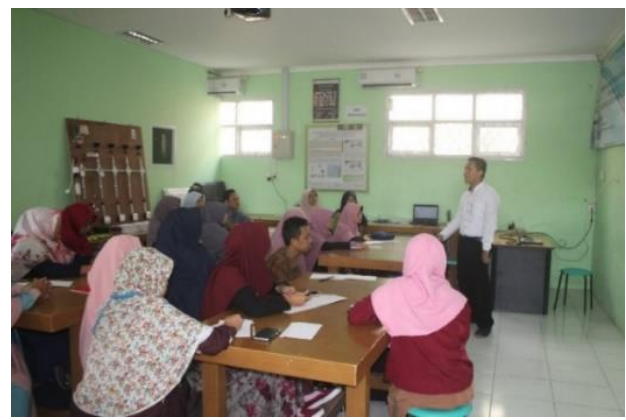

\section{Gambar 2. Pemaparan materi pembuatan alat praktikum fisika berbasis HOTS}

Peserta workshop sangat aktif mengajukan berbagai pertanyaan yang berkaitan dengan alat praktikum fisika berbasis HOTS dan mengutarakan permasalahan serta kendala yang mereka miliki pada saat melaksanakan praktikum di sekolah dan keterbatasan alat praktikum yang ada di sekolah masing-masing. Terjadi dialog dua arah yang aktif dalam kegiatan ini. Para peserta sangat antusias dalam mengikuti kegiatan ini karena mereka menganggap bahwa kegiatan ini sangat penting dan dapat memberikan informasi bagi mereka mengenai pengertian dari HOTS, bagaimana alat praktikum fisika berbasis HOTS, serta bagaimana cara pembuatan alat praktikum fisika berbasis HOTS.

Pada pelaksanaan kegiatan workshop, peserta ikut dalam pembuatan alat praktikum fisika seperti ditunjukkan pada Gambar 3. Dengan disediakannya alat dan bahan pembuatan alat praktikum yang dipandu oleh fasilitator, memudahkan peserta untuk membuat dan merakit alat praktikum fisika. Alat praktikum fisika yang dibuat berupa Hukum Ohm dan motor listrik. Sebelum pelaksanaan pembuatan alat praktikum, peserta diperkenalkan terlebih dahulu mengenai alat dan bahan apa saja yang digunakan dan bagaimana cara menggunakan alat dengan baik dengan keselamatan kerja tetap terjaga. Lalu peserta dipandu oleh fasilitator dalam merangkai dan juga merakit alat praktikum.

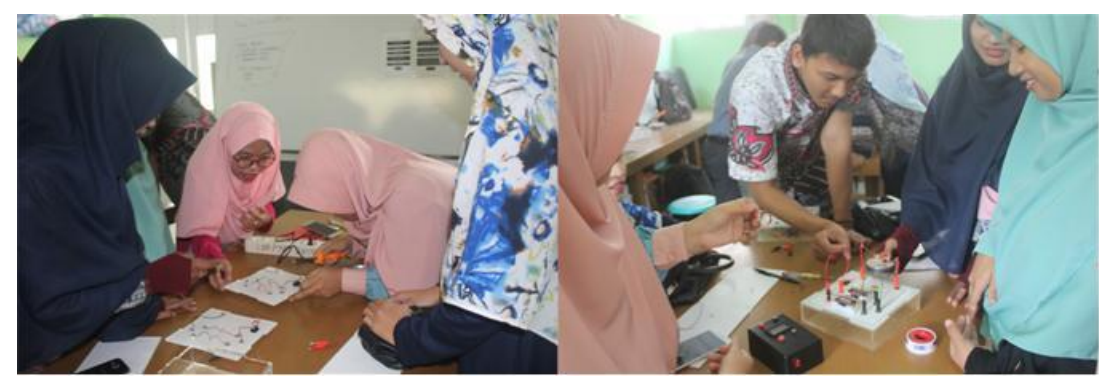

\section{Gambar 3. Para guru madrasah sedang mencoba membuat alat praktikum fisika didampingi oleh fasilitator.}

Pada pelaksanaaan pembuatan alat praktikum fisika, terlihat antusias yang sangat besar dari peserta kegiatan. Pada pelaksanaan pembuatan alat praktikum fisika ini diharapkan agar alat yang dibuat dapat dimanfaatkan dalam kegiatan belajar mengajar di sekolah masingmasing. Hasil alat praktikum yang telah dibuat oleh guru-guru madrasah bersama fasilitator kemudian disimpan di Laboratorium Vokasional Pendidikan Teknik Elektro, yang kemudian akan diujicobakan keesokan harinya dan akan dibuatkan petunjuk praktikumnya. 
Kegiatan Workshop penyusunan panduan praktikum fisika berbasis HOTS untuk guru madrasah se-Kota Serang dilaksanakan pada hari Selasa, tanggal 29 Mei 2018 di Laboratorium Vokasional Pendidikan Teknik Elektro FKIP Untirta seperti pada Gambar 4. Narasumber pada kegiatan workshop ini adalah Asep Saefullah, S.Pd, M.Si dari FKIP Untirta. Awalnya, narasumber memberikan angket kepada setiap peserta workshop untuk mengetahui pengetahuan awal peserta mengenai pembelajaran berbasis HOTS. Hasilnya menunjukkan sekitar $85 \%$ peserta belum mengetahui pembelajaran berbasis HOTS, namun seluruh peserta berminat melaksanakan pembelajaran fisika berbasis HOTS melalui kegiatan praktikum di sekolah.

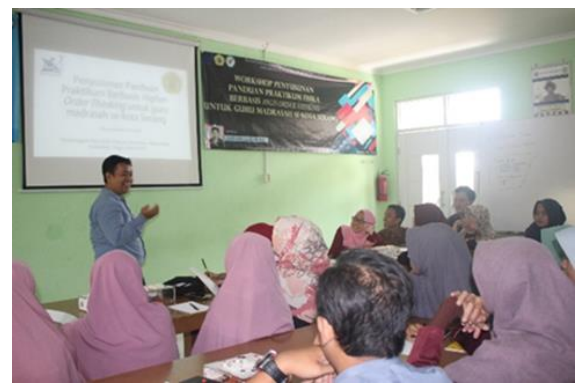

\section{Gambar 4. Pemaparan materi penyusunan petunjuk praktikum fisika berbasis HOTS}

Pembicara kemudian memaparkan materi mengenai panduan praktikum berbasis HOTS dan memberikan beberapa contohnya. Selanjutnya diadakan sesi tanya jawab bagi peserta workshop. Para peserta workshop yang terdiri dari 25 orang guru madrasah terlihat sangat antusias dalam mengikuti workshop tersebut. Para peserta workshop mengajukan beberapa pertanyaan yang berkaitan dengan panduan praktikum fisika berbasis HOTS dan mengutarakan permasalahan-permasalahan yang mereka miliki pada saat melaksanakan praktikum di sekolah dan kendala dalam membuat panduan praktikum fisika yang baik dan benar. Dalam kegiatan ini terjadi interaksi aktif antara pembicara dan peserta workshop. Kegiatan ini sangat bermanfaat karena memberikan pengetahuan mengenai panduan praktikum fisika yang baik dan berbasis HOTS sehingga para peserta sangat antusias dalam mengikuti kegiatan ini.

Pada pelaksanaan kegiatan "Workshop Penyusunan Panduan Praktikum Fisika Berbasis HOTS untuk Guru Madrasah Se-Kota Serang" peserta kegiatan dibagi dalam 4 kelompok. Dan masing-masing kelompok membuat minimal 1 panduan praktikum fisika berbasis HOTS. Pada pelaksanaan kegiatan pembuatan panduan praktikum fisika, peserta dapat mengaplikasikan materi yang sudah diberikan pada kegiatan workshop penyusunan panduan praktikum. Pada kegiatan ini peserta saling berdiskusi dalam kelompok atau juga dengan pemateri dalam pembuatan dan penyusunan panduan praktikum yang baik dan benar seperti disajikan pada Gambar 5. Sehingga kegiatan pembuatan panduan praktikum fisika ini dapat membantu peserta dalam kegiatan belajar mengajar di sekolah. Dari kegiatan workshop pembuatan alat praktikum fisika berbasis HOTS dihasilkan dua jenis alat fisika, yaitu kit praktikum hukum Ohm dan kit praktikum motor listrik. Masing-masing kit praktikum diduplikasi sebanyak 4 buah, sehingga kedua sekolah mitra masing-masing mendapatkan hibah 4 alat praktikum fisika.

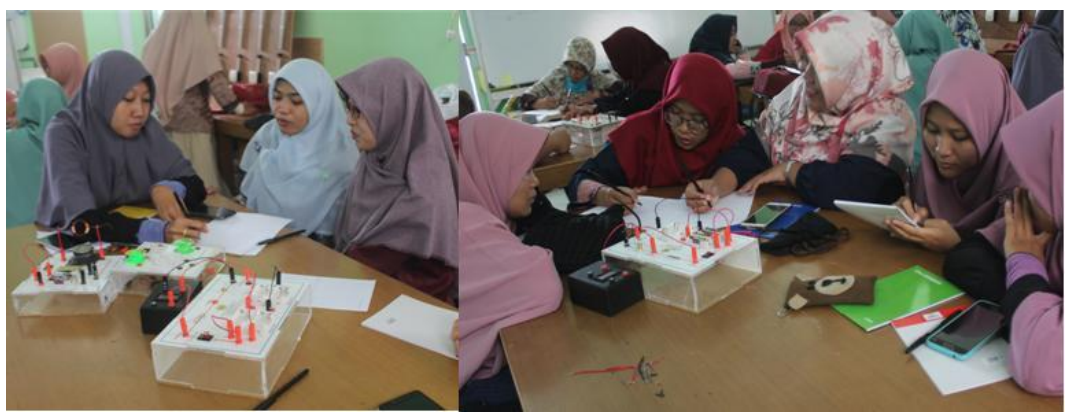

Gambar 5. Guru-guru madrasah sedang membuat panduan praktikum fisika berbasis HOTS 
Alat praktikum seperti pada Gambar 6, kemudian dihibahkan pada madrasah mitra, yaitu MA Al Rahmah dan SMAIT Nuur El Bantany. Dengan dihibahkannya alat-alat tersebut, diharapkan dapat meningkatkan proses pembelajaran di sekolah sehingga dapat meningkatkan keterampilan berfikir tingkat tinggi pada siswa-siswi madrasah di Kota Serang.

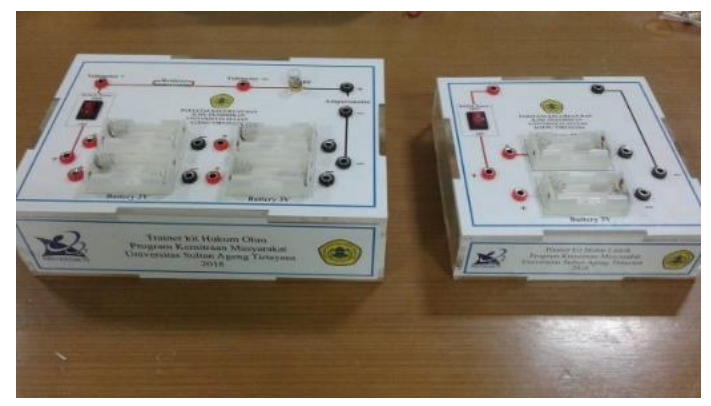

\section{Gambar 6. Trainer kit praktikum hukum Ohm dan motor listrik yang dihibahkan pada madrasah mitra pengabdian}

Kegiatan workshop pengabdian pada masyarakat juga menghasilkan panduan praktikum berbasis HOTS yang dibuat oleh para guru madrasah mitra. Hasil panduan praktikum tersebut diperbaiki agar dapat disesuaikan dengan kondisi siswa-siswi di sekolah.

Dari data hasil angket yang dibagikan terhadap peserta, seluruh peserta tertaik menerapkan pembelajaran fisika berbasis HOTS, utamanya berbasis kegiatan praktikum. Tabel 2 berikut ini menunjukan kondisi sebelum dan setelah pelaksanaan workshop.

Tabel 2. Hasil angket sebelum dan sesudah pelaksanaan workshop

\begin{tabular}{|c|l|c|c|}
\hline No & \multicolumn{1}{|c|}{ Pernyataan } & Sebelum (\%) & Sesudah (\%) \\
\hline 1 & $\begin{array}{l}\text { Banyak peserta yang mengetahui pembelajaran } \\
\text { berbasis HOTS }\end{array}$ & 30 \\
\hline 2 & $\begin{array}{l}\text { Banyak peserta yang tertarik untuk melakukan } \\
\text { pembelajaran berbasis HOTS }\end{array}$ & 88 \\
\hline 4 & $\begin{array}{l}\text { Banyak peserta yang pernah \& akan mencoba untuk } \\
\text { membuat alat praktikum sendiri }\end{array}$ & 8 & 92 \\
\hline 5 & $\begin{array}{l}\text { Banyak peserta yang pernah \& akan membuat } \\
\text { panduan praktikum }\end{array}$ & 88 \\
\hline 6 & $\begin{array}{l}\text { Banyak peserta yang berminat melaksanakan } \\
\text { pembelajaran berbasis HOTS melalui kegiatan } \\
\text { praktikum }\end{array}$ & 8 & 80 \\
\hline
\end{tabular}

Berdasarkan Tabel 2, terlihat bahwa masih minim pengetahuan dan ketertarikan mengenai pembelajaran berbasis HOTS. Setelah dilaksanakannya workshop pembuatan alat dan panduan praktikum berbasis HOTS, terdapat peningkatan pengetahuan dan minat guru dalam pembelajaran berbasis HOTS, utamanya berbasis praktikum. Selain itu, juga terlihat bahwa, sangat sedikit guru yang mampu membuat alat praktikum sendiri untuk kebutuhan pembelajaran, melalui workashop pembuatan alat praktikum, terlihat peningkatan minat guru untuk membuat alat praktikum sndiri, sesuai dengan kebutuhan pembelajaran di sekolah. Hasil pendampingan di sekolah juga menunjukan bahwa alat praktikum yang telah dihibahkan pada pihak sekolah, mampu dimanfaatkan untuk kegiatan praktikum.

\section{KESIMPULAN}

Telah dilaksanakan worskhop pembuatan alat praktikum fisika berbasis HOTS berserta penyusunan panduannya untuk guru madrasah se-Kota Serang. Kegiatan workshop ini dihadiri oleh 25 peserta dari madrasah mitra dan di luar mitra pengabdian. Kegiatan workshop dilaksanakan pada tanggal 28-29 Mei 2018. Dari kegiatan tersebut, dihasilkan dua jenis kit praktikum hukum Ohm dan kit praktikum motor listrik. Masih perlu adanya upaya pendampingan agar panduan praktikum lebih baik dan sesuai dengan kebutuhan siswa, sehingga mampu meningkatkan keterampilan berfikir tingkat tinggi pada siswa melalui kegiatan 
praktikum. Kegiatan workshop mampu meningkatkan keterampilan guru madrasah dalam hal membuat alat praktikum fisika disertai dengan panduan praktikumnya. Hal tersebut diharapkan menjadi pemacu guru madrasah untuk berinovasi membuat alat praktikum lainnya, sesuai dengan kebutuhan di madrasah sehingga diharapkan dapat meningkatkan kualitas pembelajaran. Pemberian hibah alat praktikum kepada madrasah mitra, diharapkan dapat menambah peralatan penunjang praktikum fisika, sehingga dapat meningkatkan kualitas pembelajaran, dan mampu meningkatkan keterampilan berfikir tingkat tinggi pada siswa madrasah

\section{UCAPAN TERIMA KASIH}

Ucapan terimakasih kami sampaikan pada Direktorat Riset dan Pengamdian pada masyarakat (DRPM) Kementerian Riset Teknologi dan Pendidikan Tinggi (Kemenristek Dikti) yang telah membiayai penelitian ini melalui hibah pragram kemitraan masyarakat (PKM) Kemenristek Dikti.

Terimaksih juga kami ucapkan kepada Vaka Gustiono dan Seno Indriyanto dari Jurusan Pendidikan Teknik Elektro, serta Resty Dwi Asry dan Hayin Rosdiana Azhari dari Jurusan Pendidikan Fisika yang telah menjadi fasilitasor dalam acara pengabdian kepada masyarakat ini.

\section{DAFTAR PUSTAKA}

[1] J. Delors, Education for Tomorrow, New York: United Nations Educational, Scientific and Cultural, 1996.

[2] N. Mutiara, "Pengembangan Media Pembelajaran Fisika Simulasi Komputer Menggunakan Macromedia Flash 8.0 Pada Materi Alat Optik," in Prosiding Seminar Nasional Pendidikan Fisika Untirta, Serang, 2019.

[3] R. Sundari, "Evaluasi pemanfaatan laboratorium dalam pembelajaran biologi di Madrasah Aliyah Negeri se-Kabupaten Sleman," Jurnal Penelitian dan Evaluasi Pendidikan, vol. 12, no. 2, pp. 196-212, 2008.

[4] A. Saefullah, "Reconstruction of Teaching Materials with Socio-Scientific Issues Context on Source of Energy Content," in Journal of Physics: Conference Series, Bandar Lampung, 2020.

[5] A. T. Ningsih, "EMOSETS: Pengembangan E-Modul Berbasis Science, Environment, Technology, and Society (SETS) Materi Fluida Dinamis," in Prosiding Seminar Nasional Pendidikan Fisika Untirta, Serang, 2020.

[6] N. Rapi, "Implementasi model pembelajaran inkuiri terpimpin dalam pembelajaran fisika untuk meningkatkan hasil belajar pada siswa kelas X SMA Negeri 2 Singaraja," Jurnal Pendidikan dan Pengajaran UNDIKSHA, vol. 41, no. 1, pp. 170-185, 2008.

[7] A. Saefullah, "Blended Learning: The Effect on Higher Order Thinking Skills (HOTS) in Thermodynamics," Indonesian Journal of Science and Mathematics Education, vol. 3, no. 3, pp. 262-271, 2020.

[8] A. Smith, "Education in the twenty-first century: Conflict, reconstruction and reconciliation," Compare: A Journal of Comparative and International Education, vol. 35, no. 4, pp. 373391, 2005.

[9] B. Subali, "Pengembangan kreativitas keterampilan proses sains dalam aspek kehidupan organisme pada mata pelajaran IPA SD," Jurnal Cakrawala Pendidikan, vol. 3, no. 3, pp. 365-381, 2013.

[10] A. Saefullah, "Efforts to improve scientific literacy of students through guided inquiry 
learning based on local wisdom of Baduy's society," Jurnal Penelitian dan Pembelajaran IPA, vol. 3, no. 2, pp. 84-91, 2017.

[11] J. Van Driel, "Professional development and reform in science education: The role of teachers' practical knowledge," Journal of Research in Science Teaching: The Official Journal of the National Association for Research in Science Teaching, vol. 38, no. 2, pp. 137-158, 2001.

[12] N. Rustaman, "Perkembangan penelitian pembelajaran berbasis inkuiri dalam pendidikan sains," in Seminar Nasional II Himpunan Ikatan Sarjana dan Pemerhati Pendidikan IPA Indonesia bekerja sama dengan FPMIPA UPI, Bandung, 2005.

[13] A. Purwanto, "Kemampuan berpikir logis siswa SMA Negeri 8 kota Bengkulu dengan menerapkan model inkuiri terbimbing dalam pembelajaran fisika," EXACTA, vol. 10, no. 2, pp. 133-135, 2012.

[14] A. Saefullah, "Rancang Bangun Alat Praktikum Hukum Ohm Untuk Memfasilitasi Kemampuan Berfikir Tingkat Tinggi (Higher Order Thinking Skills)," Gravity: Scientific Journal of Research and Learning Physics, vol. 4, no. 2, pp. 81-89, 2018. 